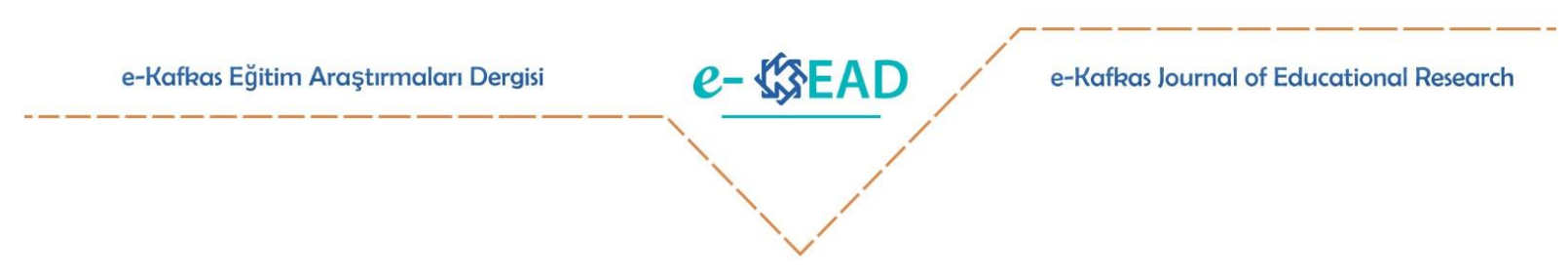

\title{
The Effect of STEM Activities on Students' Academic Achievement and Problem Solving Skills: Matter and Heat Unit ${ }^{1}$
}

\author{
Müberra Nağaç ${ }^{2}$ Serpil Kalaycı $^{3}$ \\ To cite this article: \\ Nağaç, M. \& Kalaycı, S. (2021). The effect of STEM activities on students' academic achievement \\ and problem solving skills: Matter and heat unit. e- Kafkas Ĕgitim Araştırmaları Dergisi, 8, 480-498. \\ doi:10.30900/kafkasegt.964063
}

Research article
Received:07.07.2021
Accepted:16.11.2021

\begin{abstract}
The aim of this study is to examine the effect of instructional design applications prepared in accordance with the Science, Technology, Engineering and Mathematics (STEM) approach based on the 5E model in the subject of "Matter and Heat" unit on the academic achievement and problemsolving skills of sixth grade students. The research was carried out with a mixed research design. In the quantitative dimension of the study, quasi-experimental design with pretest-posttest control group was used. The study group consists of sixth grade students in a secondary school located in the district center of a metropolitan city in the Mediterranean region. The "Matter and Heat" unit was explained through the STEM education course plan integrated in 5E learning model in the experimental group and through the current course plans as required by the curriculum in the control group. As a data collection tool, the "Matter and Heat Achievement Test" and the "Problem Solving Inventory" were applied to both groups before and after STEM education. In order to support the qualitative dimension of the mixed research, the "Semi-Structured Interview Form" was filled in to get the opinions of the students in the experimental group about STEM education and it was analyzed using descriptive statistics. As a result, it was determined that STEM education did not make a statistical difference in students' academic performance and problem-solving skills. However, the opinions of the students revealed that STEM education increased student engagement in the course that classes were more fun with STEM education, and that using this education in classes would be better for student learning.
\end{abstract}

Keywords: STEM, matter and heat unit, academic performance, problem solving inventory

\footnotetext{
${ }^{1}$ This research is derived from the master thesis study accepted by Hatay Mustafa Kemal University, Institute of Natural and Applied Sciences.

2 (iD) Master, Hatay Mustafa Kemal University, Instutate of Natural and Applied Sciences, Turkey

3 (D) Corresponding Author, Assistant Professor, skalayci@mku.edu.tr, Hatay Mustafa Kemal University, Faculty of Education, Turkey
} 


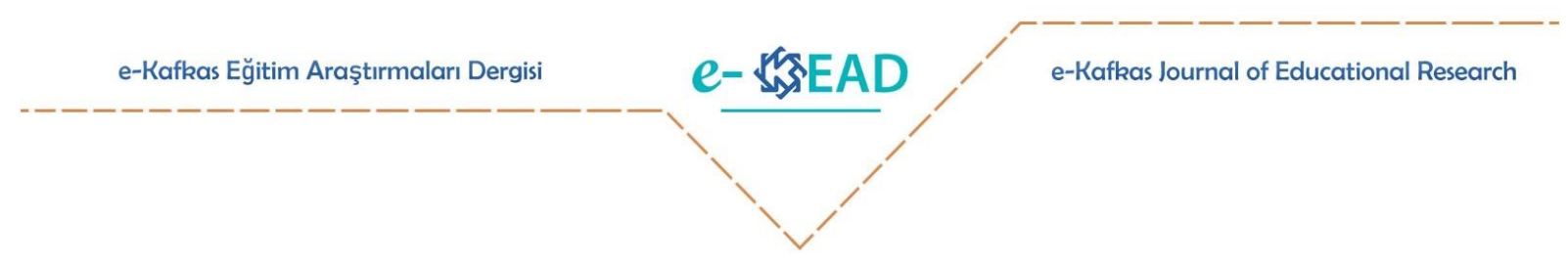

\title{
STEM Etkinliklerinin Öğrencilerin Akademik Başarı ve Problem Çözme Becerilerine Etkisi: Madde ve Isı Ünitesi ${ }^{1}$
}

\author{
Müberra Nağaç $^{2} \quad$ Serpil Kalaycı $^{3}$
}

Atıf:

Nağaç, M. ve Kalayc1, S. (2021). The effect of STEM activities on students' academic achievement and problem solving skills: Matter and heat unit. e- Kafkas Ë̆itim Araştırmaları Dergisi, 8, 480-498. doi:10.30900/kafkasegt.964063

\section{Araştırma Makalesi}

Geliş Tarihi:07.07.2021

Kabul Tarihi: 16.11 .2021

\section{$\ddot{O} \mathbf{z}$}

$\mathrm{Bu}$ çalışmanın amacı, Fen bilimleri dersi Madde ve Isı ünitesinin öğretiminde 5E modeli ile temellendirilmiş Bilim, Teknoloji, Mühendislik ve Matematik (STEM) yaklaşımına göre hazırlanan öğretim tasarımı uygulamalarının 6. sınıf öğrencilerinin akademik başarılarına ve problem çözme becerilerine etkisinin incelenmesidir. Araştırma karma araştırma deseni ile gerçekleştirilmiştir. Araştırmanın nicel boyutunda ön-test son-test kontrol gruplu yarı deneysel desen kullanılmıştır. Çalışma grubu Akdeniz bölgesinde yer alan bir büyükşehirin ilçe merkezine bağlı bir ortaokulun altıncı sınıf öğrencilerinden oluşmaktadır. Madde ve Isı ünitesi deney grubunda 5E öğrenme modeline entegre edilmiş STEM eğitimi ders planıyla, kontrol grubuna ise mevcut öğretim programının öngördüğü yöntem ve planlarla ders işlenmiştir. Veri toplama aracı olarak STEM eğitimi öncesinde ve sonrasında her iki gruba da "Madde ve Isı Kazanımı Testi" ve "Problem Çözme Envanteri" uygulanmıştır. Karma araştırmanın nitel boyutunu desteklemek amaciyla deney grubundaki öğrencilerin STEM eğitimine ilişkin görüşlerini almak üzere "Yarı yapılandırılmış Görüşme Formu" doldurtulmuş ve betimsel istatistikler kullanılarak analiz edilmiştir. Sonuç olarak, STEM eğitiminin öğrencilerin akademik performanslarında ve problem çözme becerilerinde istatistiksel bir fark yaratmadığı tespit edilmiştir. Ancak öğrencilerin görüşleri, STEM eğitiminin öğrenci katılımını artırdığını, STEM eğitimi ile derslerin daha eğlenceli olduğunu, bu eğitimi sınıflarda kullanmanın öğrencilerin feni öğrenmesi için daha iyi olacağını ve başka derslerde de kullanılabileceğini ortaya koymuştur.

Anahtar Sözcükler: STEM, madde ve 1sı ünitesi, akademik başarı, problem çözme envanteri

\footnotetext{
${ }^{1}$ Bu çalışma Hatay Mustafa Kemal Üniversitesi Fen Bilimleri Enstitüsü tarafından kabul edilen yüksek lisans tez çalışmasından türetilmiştir.

2 (D) Yüksek Lisans, Hatay Mustafa Kemal Üniversitesi, Fen Bilimleri Enstitüsü, Türkiye

3 (D) Sorumlu Yazar, Doktor Öğretim Üyesi, skalayci@mku.edu.tr, Hatay Mustafa Kemal Üniversitesi, Eğitim Fakültesi, Türkiye
} 


\section{Introduction}

In today's conditions, the factor that enables the economic development and progress of countries is innovation in technology. For this reason, it is a great importance to train the next generation as science and technology literate and to make engineering common (Miaoulis, 2009). STEM (Science, Technology, Engineering and Mathematics)education; In terms of enabling the transformation of theoretical knowledge in the fields of Science, Technology, Engineering and Mathematics into applications and products (Akgündüz et al., 2015a; Çorlu, Adıgüzel, Ayar, Çorlu \& Özel, 2012) and in terms of its contribution to the advancement and development of science and technology as well as its sustainability, researches reveal that STEM education is very important (Akgündüz et al., 2015a; Akgündüz, Ertepınar, Ger, Kaplan Sayı, \& Türk, 2015b; TUSIAD, 2014).

STEM; is an educational approach based on the idea of educating students in science, technology, engineering, and mathematics with an interdisciplinary approach. STEM provides interdisciplinary interaction by emphasizing activity-based learning (Akgündüz et al., 2015b; Bybee, 2010). STEM aims to raise individuals who have high self-confidence and strong communication skills, can think creatively, solve problems, and know how to use tools, understand mechanisms, and come up with original ideas (Bybee, 2010). In STEM education it has been stated that STEM improves students' rational, creative, and inquisitive thinking skills and enables them to use their knowledge and skills more effectively (Morrison, 2006). STEM education applied to start from the kindergarten improves students' creative thinking skills, helping them to come out with new ideas and products, stimulates their curiosity, and increases their interest in science and technology (Altun \& Yildirım, 2015). The student can direct his/her imagination in line with the knowledge he/she has acquired as well as obtain the ability to solve problems with his/her creative skills (Roberts, 2012). Özdemir (2016), who advocated that STEM will affect the personality traits of the individual thanks to the products created in the cognitive development process, stated that characteristics such as entrepreneurial spirit and respecting oneself, others, and the environment would develop in the individual. Özdemir (2016) also stated that students who were grown up with STEM education could easily overcome the difficulties they encounter in order to achieve their dreams.

According to Koştur (2017), the individual has drawn a road map for himself in line with the needs of every age. Table 1 shows that the skills required by the current century are almost parallel to each other in Table 1, as there is not much difference between the skills required to be gained in STEM education and the skills gained in science education in our country.

Table 1.

The Relationship between 21st Century Skills, STEM Education and Science Education in Turkey

\begin{tabular}{lll}
\hline 21st century skills & STEM Education & Science Education in Turkey \\
\hline Information literacy & Communication & Research-inquiry \\
Critical thinking & To decide & Learning to access information \\
Entrepreneurship & Reasoning & Critical thinking \\
Communication & Confidence & Effective decision making \\
Cooperation & Self-management & Science and career awareness \\
To decide & Problem solving & Entrepreneurship \\
Leadership & Systems thinking & Communication \\
Curiosity and imagination & Social skills & Cooperation \\
Learning to learn & Technology literate & Curiosity \\
Problem solving & Adapt & Confidence \\
Responsibility & Creativity & Problem solving \\
Adapt & Being innovative & Responsibility \\
Creativity & & Creative thinking \\
Life and career information & & Life skills \\
& & Lifelong learning \\
\hline
\end{tabular}

As seen in Table 1, creativity, critical thinking, collaborative work and problem solving are among the 21st century skills. These gains, which seem simple but are the sparks of inter-country competition, have a universal character (Akgündüz et al., 2015a). The implementation of STEM 
education from kindergarten to university education will improve students' problem-solving skills and ability to use their imagination (Bybee, 2010).

The literature review yielded several studies related to STEM. Fortus, Dershimer, Krajcik, Marx and Mamlok Naaman (2004), concluded that STEM education increases high school 10th- and 11th-grade students' interest in science classes and improves their performance and learning levels in this course. Doppelt, Mehalik, Schunn, Silk and Krysinski (2008) determined that STEM education increases eighth grade students' interest in science and boosts their performance in this course. Ceylan (2014) demonstrated that STEM increases students' academic success, creativity, and problem-solving skills on the subject of "Acids and Bases". In a study that investigated the success of students who switched to schools providing STEM education, Şahin, Ayar and Adigüzel, (2014) found that extracurricular STEM education increase student engagement, improve their group work skills, and have an impact on their choice of profession. Yamak, Bulut and Dündar (2014), concluded that STEM education lead to improvements in students' scientific process skills and help them develop positive attitudes towards science. Altun and Yildirım (2015) determined that the Science laboratory course using the STEM increased prospective teachers' academic success. In a study with seventh grade students, Y1ldırım and Selvi (2016) reported that STEM and mastery learning positively affected students' academic success and motivation for science classes but did not lead to a statistically significant difference in students' attitudes towards STEM. Irkıçatal (2016) concluded that extracurricular STEM education positively affected seventh grade students' academic performance in the subject of "Simple Machines". Saçan (2018) found that the STEM-based curriculum improves the scientific process skills of seventh grade students, increases their motivation towards STEM, and positively affects their attitudes towards socio-scientific issues. Toma and Greca (2018) observed that the integrative STEM learning model based on inquiry helped students to develop positive attitudes towards science and increased their academic success. In a study investigating prospective science teachers' opinions about STEM. Aslan and Bektaş (2019) stated that STEM has some positive aspects as well as financial and infrastructural problems. Ergün and Balçın (2019) concluded that learning the "Force-Motion" unit with problem-based STEM education increased students' academic success. When the studies on STEM education are examined, no research has been found in which success and problem solving skills are examined together. For this reason, it is thought that the research will be a source for academicians, educators and teachers who will work in this field.

The present study aims to investigate the effects of STEM education used in the learning of the "Matter and Heat" unit included in the science curriculum of sixth grade on the academic performance and problem-solving skills of students. The aim was to find out whether students can learn and apply interdisciplinary content, question the accuracy of the information they acquire, develop communication skills, work in collaboration, reason, and improve the competence to use technology. When the courses are taught with STEM education in accordance with the 5E model, it is thought that students can relate the unit and subjects with daily life and, collaborative working, productivity and design skills will be learned better and problem solving skills will develop. In this respect, the present study is expected to fill this gap in the literature by revealing the effects of STEM education on students' problem-solving skills.

\section{Method}

In this research, mixed research method and explanatory sequential design as design were used. In this design, firstly, the quantitative method is used. Then, qualitative methods are used to examine the results in depth (Creswell, 2019). A quasi-experimental design, which is a quantitative analysis method, was used in the research. The main purpose of this pattern is to test the cause-effect relationship between the variables. For this, the researcher needs to make random assignments to the study groups, which are the levels of the independent variable, in order to manipulate the independent variable and control the external variables (Borg \& Gall, 1989; Büyüköztürk, 2016; Hovardaoğlu, 2000; Kerlinger, 1973). Fraenkel, Wallen and Hyun (2012, p. 266), on the other hand, argue that the basic idea behind experimental research is to "Try something and systematically observe what happens". In the qualitative aspect of the research, a semi-structured interview form was applied to the experimental group students in order to determine their views on STEM applications. 


\section{Participants}

44 sixth grade students who are studying in a secondary school located in the district center of a metropolitan city in the Mediterranean region participated in the study. The group of the study was randomly divided into two groups as the experiment and the control. Of the 24 students in the experimental group, 13 (\%54) were girls and 11(\%46) were boys. Of the 20 students in the control group, 5 (\%25) were girls and $15(\% 75)$ were boys.

\section{Data Collection Tool}

Matter and Heat Achievement Test (MHAT), Problem Solving Inventory (PSI) and semistructured interview form were used as data collection tools in the study.

\section{Matter and heat achievement test (MHAT)}

The questions in the readiness test prepared by considering the "Matter and Heat" unit acquisitions were created based on various test books and the school textbook. There are a total of seven acquisitions related to the "Matter and Heat" unit. Attention has been paid to include questions about each acquisition. Each question aims to measure the acquisitions in the unit. The questions were written entirely by the researcher, as a four-way multiple choice. The test which consists of 30 questions, was examined its suitability for students by two experts in science education and acquisitions was examined. It has been examined by one language experts for its compliance with Turkish grammar rules. The test was administered to 188 seventh grade students. After the item analysis of the test, items 2, 5, 6, 13, 22 and 23 were excluded from the test. Thus, the test was reduced to 24 questions and rearranged. Later, opinions were taken by experts in their field and the success test was finalized. The Cronbach Alpha reliability coefficient of the MHAT was .70 and the average item discrimination was calculated .56. Two sample questions of MHAT are presented below in Figure 1;

1. Although there are many benches in
the park, Hasan grandfather preferred to
sit on a wooden bench rather than a
concrete one.
According to this, which of the following is
the reason why Hasan grandfather chose
the wooden bench?
A) Concrete is more insulating than wood.
B) Wood has a harder structure than
concrete.
C) Wood is more conductive than
concrete.
D) Wood is more insulating than concrete.
Reason for marking this option
2. Which of the following is false regarding geothermal energy?

A) It contains gases and chemicals in its structure.

B) It is released as a result of heat accumulating under the earth's crust.

C) It is a non-renewable energy source.

D) It can also be used for heating houses

Reason for marking this option

Figure 1. Sample Questions of MHAT

\section{Problem solving inventory (PSI)}

The Problem Solving Inventory applied in the study was developed by Heppner and Peterson (1982) and adapted to Turkish by Şahin, Şahin and Heppner (1993). The Cronbach Alpha reliability coefficient was calculated as .90, and this inventory consists of 35 items and it was aimed to evaluate students themselves about their problem solving skills. Students can get a minimum of 32 and a maximum of 192 points on this scale. The scoring of the items of the scale, which is scored between 1 and 6; 1: Totally Agree, 2: Partly Agree, 3: Slightly Agree, 4: Slightly Disagree, 5: Partially Disagree, 6: Not Agree. While scoring items 9, 22 and 29 were not scored, items 1, 2, 3, 4, 11, 13, 14, 15, 17, 21, $25,26,30$ and 34 were scored in reverse. It is assumed that the items that are not scored do not measure the problem solving skills sufficiently. 


\section{Semi-Structured Interview Form}

To reveal the students' views about STEM education, the semi-structured interview form, which was developed by the researcher, was applied to the students in the experimental group after the STEM education. The extent to which the interview form represents the opinions of middle school sixth grade students on STEM applications was determined by consulting an expert's opinion, the content and appearance validity were checked and the final form was formed after the necessary arrangements were made. The interview form included the following questions regarding STEM education;

1-Did you find the activities you did within the scope of STEM education useful in the Science course? Explain why.

2-Which of the STEM activities in the course did you like the most? Explain why.

3- Do you think that STEM education contributes to your math and engineering skills? Explain why.

4- Did you find the STEM activities useful? Explain why.

5- Do you think your STEM education should be only in math and science course s? Can it be effective in other course, as well? Please explain with reasons.

\section{Context of the Study}

Students were informed about STEM education. The students were divided into 5 groups heterogeneously. Three weeks period is defined in the science course annual plan of the 2016-2017 academic year for the matter and heat unit to be taught in the courses. Since the application lasted for 4 weeks (16 hours), an application was included every week and the worksheets that each student was asked to fill in after the applications were created. STEM education was applied in blending with 5E model. The students were asked about the content of the acquisition at the engagement stage, and they were made to focus their attention. The exploration stage was completed by watching visuals and videos on the subject that they wanted to associate with daily life. In the exploration stage, the subject was conveyed to the students in detail. In the meantime, the students were asked questions about the subject and the subject was understood. In elaboration stage, the design application related to the acquisitions were distributed to the groups and they were asked to be completed within two course hours. The products revealed at the evaluate stage were evaluated and intergroup evaluations were made. After the design process was completed, the worksheets prepared were distributed to the students and they were asked to be filled in, and feedbacks were made (Appendix). During the application, smart board applications as well as the EBA and Vitamin platform were used (Figure 2). The topics were carried out in the planned time. The applications used in the study are given below (Table 2, 3, 4 and 5).

Table 2.

The First Application

Name of the Application: We are designing colorful cups.

Purpose of the Application: To determine that the thermal conductivity of the substances are different from each other.

Required Materials: Pet bottle, can of coke, cardboard, candle, lighter, hot water and paint. Preparation of the Application: The same amount of hot water is put into handled glasses designed from different materials and the earliest heated glass is determined. It is discussed whether differences such as the width of the glass, the type of material used, and the length of its handle have any effect on the thermal conductivity.

Conclusion: The students in the groups made comments on which glass the hot water they put in the glasses they designed would be delivered faster. In order to understand which of the five glasses prepared was heating faster, they tried to understand the temperatures by touching the glasses. They inferred which glass was warmer and why and discussed in class and made general explanations. 
Table 3.

The Second Application

Name of the Application: We are designing colorful houses.

Purpose of the Application: To determine how important thermal insulation is in buildings.

Required Materials: Styrofoam, glass wool, wood, cardboard, colored paints, glue, scissors and various decorations.

Preparation of the Application: House models are prepared in the same size using different insulation materials. Then a thermometer is placed inside the models and the models are kept in sunlight for an equal time. By looking at the values on the thermometer, it is decided whether there is a difference or not. If it is different, why it is different is discussed in class.

Conclusion: They learned what thermal insulation is, what it is for, and the materials used in thermal insulation and its properties. At the same time, information was obtained on how the contribution of heat insulation to the family and country economy.

Table 4.

The Third Application

Name of the Application: We are making kerosene lamps.

Purpose of the Application: Classifying fuels as solid, liquid and gas and to illustrate them.

Required Materials: Cologne, lighter, glass bottle with metal cap, rope.

Preparation of the Application: A hole is made in the metal cap of the glass bottle. A piece of cologne is put into the bottle by cutting a thick rope slightly more than the length of the bottle, passing it through the hole and closing the cap. The rope coming out of the cover is burned with a lighter.

Conclusion: By learning how to classify solid, liquid and gaseous fuels, they have learned about the usage areas of energy obtained from fuels.

Table 5.

The Fourth Application

Name of the Application: How about making a storyboard?

Purpose of the Application: To determine the effects of fuels on the environment and to learn how to take precautions against stove poisoning.

Required Materials: Cardboard, craft paper, glue, scissors and cotton.

Preparation of the Application: Based on the events that occur in our environment, it is decided what effects the fuel has on the environment in the consumption. Separating the impact it creates in our environment into minutes, what events may occur every minute is transferred to the cardboard by considering them. The same effectiveness is adapted to measures to be taken against stove poisoning or to a family suffering from stove poisoning. Conclusion: In this study conducted by the students, it was thought about what could happen at each stage by dividing an event into stages and it was tried to develop anticipation ability. In addition, the students were encouraged to find out what kind of solutions to produce in the problem situations they may encounter in daily life.

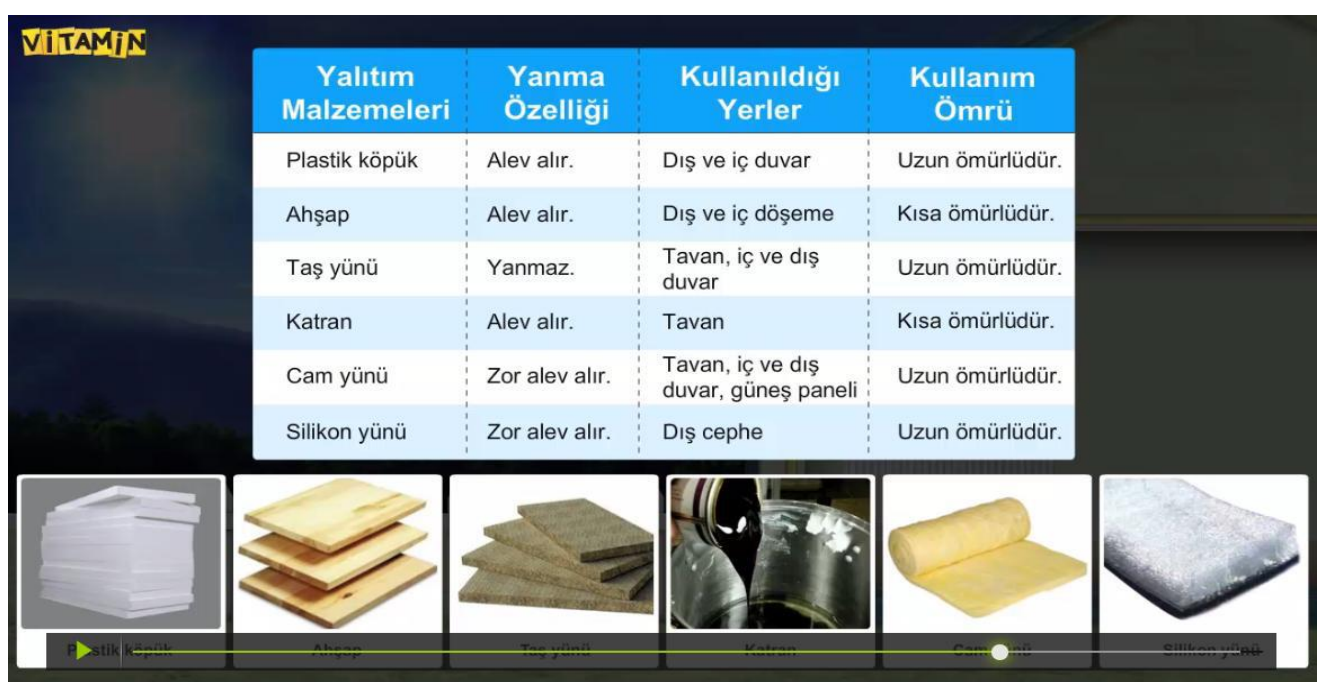

Figure 2. Smart board applications 
The subject was taught to the students in the control group using the current lesson plans as required by the curriculum. The teacher in-formed the students about the unit in order to enter the lesson, asked various questions and gathered the students' attention. The textbook determined by the Ministry of National Education was used as a source, the relevant subject was tried to be conveyed verbally in detail and important parts were written on the board. In the meantime, students were asked to write the notes on the board in their notebooks. The teacher made the necessary explanation by asking the students whether there is an incomprehensible part at the end of the subject or sub-topic. In the last part of the course, a general summary was repeated and the homework was made from the textbook.

\section{Analysis of the Data}

SPSS 20.00 package program was used to analyze the collected data. In this study, ShapiroWilk Test results and skewness-kurtosis values were examined in order to determine whether the data obtained from MHAT and PSI were suitable for normal distribution. It was determined that the data obtained showed normal distribution, and parametric tests were applied in the analysis of the data obtained from the experimental and control groups. The data obtained from the semi-structured interview questions were subjected to descriptive analysis. According to this analysis, the collected data are organized and interpreted in themes. In this analysis, direct quotations are included in order to reflect the views of the participants in a striking way (Yıldırım \& Şimşek, 2017). The frequency values of the data obtained from the interview forms were calculated. The data obtained from the interview form were evaluated separately by the researcher and 1 expert, and themes were formed. For an analysis free from individual effects, it is important to determine the similarity ratio of the results obtained from different encoders (Fidan \& Öztürk, 2015). In order to determine the reliability and internal consistency of this research, the formula $\Delta=\mathrm{C} \div(\mathrm{C}+\partial) \times 100$ proposed by Miles and Huberman (1994) was used. ( $\Delta$ : Confidence coefficient, C: Number of concepts/terms with consensus, $\partial$ : Number of concepts/terms with no consensus). According to this formula, which shows internal consistency, it is recommended that the consensus among coders should be at least $80 \%$ (Patton, 2002). As a result of the research, the consensus was found to be $89 \%$.

\section{Results}

Whether STEM affects students' academic success was tested. Also, the effect of STEM education on students' problem solving skills was investigated. In order to support the quantitative data obtained from the research, a semi-structured interview form was distributed to the students and they were asked to fill in open-ended questions. The obtained data were divided into themes and their frequencies were calculated.

\section{Findings Related to the Pretest Achievement Scores of the Students in the Experimental and Control Groups}

Findings regarding the pretest achievement scores of the experimental and control group students are presented in Table 6.

Table 6.

"T-test" Results Related to the Pretest Achievement Scores of Experiment and Control Groups

\begin{tabular}{lccccccc}
\hline Groups & $\mathrm{N}$ & $\bar{X}$ & $\mathrm{~S}$ & $\mathrm{t}$ & $\mathrm{p}$ & Kurtosis & Skewness \\
\hline $\begin{array}{l}\text { Experimental } \\
\text { group }\end{array}$ & 24 & 4.8 & 3.4 & .346 & $.351^{*}$ & .621 & .531 \\
\hline Control group & 20 & 5.9 & 4.3 & & & -.896 & .231 \\
\hline
\end{tabular}

As it can be inferred from Table 6, the t-test was conducted to determine whether there is a difference between the experimental and control groups. The t value was found to be .346. Since p> .05 , there was no significant difference between the pretest scores of the two groups. Since the Kurtosis and Skewness coefficient values in the table are between +1 and -1 , the data are suitable for normal distribution.

Findings Related to the Posttest Achievement Scores of the Students in the Experimental and Control Groups 
In the study, a posttest was applied to the experimental and control groups to measure their success levels after the STEM education (Table 7).

Table 7.

"T-test" Results Related to the Posttest Achievement Scores of Experiment and Control Groups

\begin{tabular}{lccccccc}
\hline Groups & $\mathrm{N}$ & $\boldsymbol{Z}$ & $\mathrm{S}$ & $\mathrm{t}$ & $\mathrm{p}$ & Kurtosis & Skewness \\
\hline Experimental group & 24 & 12.7 & 5.8 & .317 & $.944^{*}$ & -.920 & -.601 \\
\hline Control group & 20 & 10.9 & 6.1 & & & -.481 & -.274 \\
\hline *p $>.05$ & & & & & & &
\end{tabular}

The mean of the posttest scores of the students in the experimental group was 12.7, with a standard deviation of 5.8, whereas the mean of the posttest scores of the students in the control group was 10.9 , with a standard deviation of 6.1. As a result of calculations, $t$ value was found .317 . Since $p>$ .05 , there was no statistically significant difference between the posttest scores of the two groups.

\section{Findings Related to the PSI' Pretest of the Students in the Experimental and Control Groups}

Findings regarding the PSI' pretest scores of the experimental and control group students are presented in Table 8 .

Table 8.

"T-test" Results Related to the Pretest PSI' Scores of Experiment and Control Groups

\begin{tabular}{lccccccc}
\hline Groups & $\mathrm{N}$ & $\mathbb{Z}$ & $\mathrm{S}$ & $\mathrm{t}$ & $\mathrm{p}$ & Kurtosis & Skewness \\
\hline Experimental group & 24 & 132.5 & 22.8 & .799 & $.222^{*}$ & -.610 & .545 \\
\hline Control group & 20 & 130.9 & 18.9 & & & -.673 & -.219 \\
\hline
\end{tabular}

*p> 0.05

As can be inferred from Table 8, the mean of the PSI pretest scores of the students in the experimental group was 132.5 , with a standard deviation of 22.8 , while that of the students in the control group was 130.9, with a standard deviation of 18.9. Since p>.05, we can say they have equal variances. Therefore, there is no statistically significant difference between the PSI pretest scores of the two groups.

\section{Findings Related to the PSI' Posttest of the Students in the Experimental and Control Groups}

In the study, the PSI was applied to the experiment and control groups to measure their problem solving skills after STEM education. The results obtained are given below (Table 9).

Table 9.

Results Related to Posttest PSI' Scores of Experiment and Control Groups

\begin{tabular}{lccccccc}
\hline Groups & $\mathrm{N}$ & $\mathbb{X}$ & $\mathrm{S}$ & $\mathrm{t}$ & $\mathrm{p}$ & Kurtosis & Skewness \\
\hline Experimental group & 24 & 134.5 & 21.4 & .387 & $.218^{*}$ & -.869 & .470 \\
\hline Control group & 20 & 139.8 & 18.1 & & & .363 & -.763 \\
\hline
\end{tabular}

$$
\text { *p>.05 }
$$

As can be inferred from Table 9, the mean of the PSI posttest scores of the students in the experimental group was 134.5, with a standard deviation of 21.4, while that of the students in the control group was 139.8 , with a standard deviation of 18.1. As a result of calculations, the $t$ value was found to be .387 . Since $p>.05$, it was seen that the variances of the two groups were homogeneous and there was no statistically significant difference between the PSI posttest scores of the groups.

As the third sub problem of the study, answers were sought to the question of "What are the views of the students in the experimental group regarding STEM education?". The students' answers given to the questions in the form were analyzed, and their frequency values were determined. Frequency values were calculated for the first question (Did you find the activities you did within the scope of STEM education useful in the Science course? Explain why.) in the interview form (Table $10)$. 
Table 10.

Frequency Values for the First Question

\begin{tabular}{lc}
\hline Themes & Frequency \\
\hline $\begin{array}{l}\text { STEM events are very fun. I always want to do such an application in our } \\
\text { science class. }\end{array}$ & 11 \\
\hline $\begin{array}{l}\text { I have trouble remembering the information. Because we were not doing } \\
\text { applications in science class. }\end{array}$ & 9 \\
\hline
\end{tabular}

Nine students believed that when they memorize for the course, they easily forget or have difficulty remembering what they learn. Two excerpts from the interview forms related to this question are as follows:

"Before STEM education, we used to have traditional classes, and I had difficulty remembering, I had to memorize (S2)" and "The applications we do in the science class are useful for me. Because if we learn the course by turning it into a game, we can remember better what we have learned and the course becomes more fun (S5)."

Frequency values were calculated for the second question (Which of the STEM activities in the course did you like most? Explain why.) in the interview form (Table 11).

Table 11.

Frequency Values for the Second Question

\begin{tabular}{lc}
\hline Themes & Frequency \\
\hline I loved the application of designing colorful cups. & 6 \\
\hline I liked the design of a heat insulated house more. & 5 \\
\hline I liked the application about stove poisoning more. & 2 \\
\hline
\end{tabular}

Six students stated that their favorite application was "designing colorful cups," five students stated that it was "heat-insulated house model," and two students stated that it was "the slow-motion about carbon monoxide poisoning from a wood-burning stove." One of the excerpts from the interview forms related to this question is as follows:

"I most liked the slow-motion about carbon monoxide poisoning from a wood-burning stove. Because, to me, it was the most meaningful application. Since we animated carbon monoxide poisoning, everyone understood very well what to do. Some of us didn't even know anything about poisoning from a stove. But they learned it. I think it was a very fun application (S6)."

Frequency values were calculated for the third question (Do you think that STEM education contribute to your math and engineering skills? Explain why.) in the interview form (Table 12).

Table 12.

Frequency Values for the Third Question

\begin{tabular}{lc}
\hline Themes & Frequency \\
\hline I think it has contributed to the engineering field. & 12 \\
\hline He contributed to our knowledge of mathematics and engineering. & 11 \\
\hline I think I improved myself with what I learned. & 8 \\
\hline My dexterity has improved. & 6 \\
\hline I do not think it has contributed much to the field of mathematics. & 1 \\
\hline
\end{tabular}

It was found that twelve students believed that STEM education made classes more fun, the applications were useful, and STEM education contributed to their engineering design process. The student with code $\mathrm{S} 8$ wrote the following statements related to this:

"We made a house model for engineering and (this application) was very effective. We took measurements (for the house model), attached (cardboards) together, and had a lot of fun. I think it has improved our engineering skills."

Eleven students stated that STEM education contributed to their both mathematics and engineering knowledge and helped them develop positive attitudes towards science classes. For example, S5 stated,

"The applications improved both our math and engineering skills. In the applications, we measured, cut, and, by doing so, improved our math skills. We learned what is used in heat- 
insulated houses. This, in turn, improved our engineering skills. I believe that these applications will contribute to both mathematics and engineering skills."

Eight students believed that what they learned through the STEM education helped them improve themselves:

"I improved myself in science classes, and this affected me significantly. These applications are very important to us. These applications can even cause changes in our lives. Take the example of poisoning from a stove. Maybe, one of our families will experience this one day. Since we have learned what to do in case of poisoning from a stove, maybe we can save that family (S4)."

Frequency values were calculated for the fourth question (Did you find the STEM activities useful? Explain why.) in the interview form (Table 13).

Table 13.

Frequency Values for the Fourth Question

\begin{tabular}{lc}
\hline Themes & Frequency \\
\hline The applications were very nice and fun. & 12 \\
\hline I find the applications we do very useful & 12 \\
\hline It increased my interest in the course. & 10 \\
\hline Performance has increased in written exams. & 8 \\
\hline I understand it easily. & 5 \\
\hline My perspective on science has changed. & 4 \\
\hline I apply what I learned to life. & 3 \\
\hline My interaction with my friends got stronger during the event. & 3 \\
\hline My imagination improved. & 2 \\
\hline
\end{tabular}
S4 stated

Ten students believed that STEM education increased their interest in the course. For example,

"Using such applications in future classes will certainly increase my interest in the class."

Similarly, with regards to the effects of STEM education on written exams, S1 stated,

"With these applications, I understood the subjects I had not understood before and I could answer the questions in the written exam which I could not answer before. I wouldn't have been able to answer them if we had not learned the course in this way." Also, S4 stated, "(STEM applications) help us to understand the subjects well and to perform well in exams."

Three students believed that STEM education helped them apply their learnings to daily life. A sample excerpt related to this is as follows:

"I find STEM useful. Because they help people learn new things and apply them to daily life (S10).”

Three students reported that their interaction with their friends got stronger, $16 \%$ reported that their imagination improved. For example, S2 stated,

"Thanks to these applications, I improved my relationships with my friends. I couldn't imagine these things before. I can now imagine thanks to STEM."

Frequency values were calculated for the fifth question (Do you think your STEM education should be only in math and science courses? Can it be effective in other courses, as well? Please explain with reasons.) in the interview form (Table 14).

Table 14.

Frequency Values for the Fifth Question

\begin{tabular}{lc}
\hline Themes & Frequency \\
\hline STEM should be adapted to all courses. & 11 \\
\hline STEM should be adapted to Turkish course. & 3 \\
\hline It should be adapted to the social studies course. & 3 \\
\hline $\begin{array}{l}\text { STEM should be applied not only to one subject but to all subjects of science } \\
\text { course. }\end{array}$ & 2 \\
\hline STEM should be in science only. & 1 \\
\hline
\end{tabular}


Eleven students agreed on the adaptation of STEM education to all courses. For example, S8 stated,

"Before these applications, we used textbooks in courses and we didn't do many applications. That's why I had difficulty understanding the subject properly. But STEM helped us learn by doing." Also, S4 stated, "Such applications will increase our motivation and interest in other courses, as well."

Three students stated that STEM education should be adapted to Turkish courses, one student stated that they should be used only in science classes, and three students stated that they should be adapted to social studies classes. For example, S8 stated,

"These applications can be used in Turkish classes. Because I'm having trouble with subjects such as haplology or consonantal effects in Turkish classes. I can understand these subjects better through applications."

Another student stated,

"STEM applications should be used only in science classes. If we use them in other classes, we may be confused. It would be good to use them only in one course (S11)."

On the other hand, S7 stated,

"I am good at math and science courses, but not so good at social studies. So these applications should be used in social studies classes, as well."

Two students stated that STEM education should be adapted to all subjects, not a single subject, in science classes, and one student said that STEM education did not contribute to the mathematics field. For example, S7 stated,

"Actually, I do not think STEM have contributed much to the mathematics field. Because we didn't do much math's in these applications. But I think they have many contributions to the engineering field."

\section{Discussion and Conclusion}

The aim of this study is to examine the effects of STEM education on sixth grade students of academic achievement and problem solving skills in "Matter and Heat" unit. At the same time, quantitative data were tried to be supported by semi-structured interviews with students after the application.

While teaching the "Matter and Heat" unit in the science course, studies on STEM Education were carried out and it was concluded that these studies made a difference on students' achievement, but this difference was not statistically significant. However, considering the post-test results, an increase was observed in favor of the experimental group. This shows that STEM activities are still successful in increasing academic achievement. When the literature is examined, it is seen that STEM education generally increases the academic success of students (Altun \& Yildirım, 2015; Ceylan, 2014; Doppelt et al., 2008; Erdoğan, Çorlu \& Capraro, 2013; Marulcu \& Höbek 2014; Satchwell \& Loepp 2002; Wendell \& Lee, 2010; Y1ldırım \& Selvi, 2016; Zeynegiller, 2006). In this respect, research results differ from other studies. It is thought that teachers and students have difficulties in getting used to a new education model as the traces of traditional education continue. This may have limited the impact of STEM education. According to the results obtained from the qualitative data, it was seen that the students found STEM activities nice, fun and useful, their interest in the course increased, and their imaginations developed.

In the engineering design process, it was observed that students could not generate original models or ideas by using their imagination and they needed a sample model to take as an example. During the group works, it was observed that the students could not cooperate efficiently with each other and that only a few students fulfilled their responsibilities. As the engineering design phase is time consuming, sometimes insufficient time allocated may have triggered this situation. Also, it is thought that since traditional learning methods have deep traces on students, they had difficulty adapting to a new learning model. Marulcu and Höbek (2014) think that the teacher who performs the 
application will not have any problems in time management when familiar with the engineering design method.

In the two-stage achievement test applied to the students, it was found that most students could not write any "Reasons for choosing this option," which they were asked to write for every question. On the other hand, those who wrote reasons could not provide sufficient information. Due to certain requirements of our education system, more emphasis is put on multiple choice questions or tests in schools or courses. Therefore, when open-ended questions are asked to students or when students are asked to express their views, they have difficulties expressing themselves or writing in an effective way what they think. In the second stage of the test, some of the students said, "I just cannot write anything, can I please be excused from writing?" "Because this is how we learned in the class," or "I opted for this option because I felt it is true."

The effect of STEM education on problem solving skills was also examined and it was concluded that STEM education did not contribute to the problem solving skills of the students. Unlike the results of this study, Parno et al., (2020) found that Project Based Learning-Science Technology Engineering and Mathematics (PjBL-STEM) application increased students' problem solving skills. Similarly, Yamak et al., (2014) reported that STEM education improved students' scientific process skills such as identifying and defining a problem, researching, questioning, and solving problems and that the designs made by students in the classroom helped them develop a positive attitude towards science classes. Strong (2013) observed that the engineering design process applied to elementary school students improved their scientific process skills. The present study and the studies in the literature do not support each other. It was seen that the students expected guidance from outside instead of producing practical solutions to the events they encountered in daily life. It is thought that this situation limits students' problem solving skills.

When the students' answers to the questions in the interview form are examined, most think that STEM education was generally useful, made classes more fun, helped them develop positive attitudes towards science classes, and increased their interest in and motivation for science classes. Yamak et al. (2014) reported that the designs and activities in science classes contributed to fifth graders' science process skills and helped them develop positive attitudes towards science classes. This result also supports other research in the literature (Çavaş, Bulut, Holbrook \& Rannikmae, 2013; Doppelt et. al., 2008; Harkema, Jadrich \& Bruxvoort, 2009; Moore, Stohlmann, Wang, Tank \& Roehrig, 2013). The present study found that STEM education improved students' engineering skills, helped them build better relationships with their classmates, and contributed to the development of creative thinking skills. Besides, $50 \%$ of the students stated that their manual skills improved and $92 \%$ of them said that their mathematics and engineering skills improved. This result is consistent with some studies in the literature. In a TUBITAK supported project with the participation of sixth grade students studying in disadvantaged areas, Baran, Canbazoglu Bilici, Mesutoglu and Ocak (2016) aimed to change and improve the students' attitudes towards science classes. In the research, 13 different modules related to the STEM were applied. At the end of the study, it was observed that students' scientific process skills, manual skills, mathematics, engineering, science, and design skills improved.

Since science, technology, mathematics, and engineering are integrated disciplines and they appear in many areas in our everyday life, it has become a necessity to integrate them all into the curriculum with an interdisciplinary approach (Moore et. al., 2013). Therefore, the science curriculum should be strengthened with STEM education. At the same time, the desired objectives can be achieved by making arrangements in the content of the textbooks, increasing the number of science classes, or putting more emphasis on extracurricular activities. As factors that prevent the implementation of STEM education. Akgündüz et al., (2015b) addressed factors such as lack of necessary infrastructure, insufficient resources allocated to education, and the fact that radical changes to be made in the curriculum will take a long time. By eliminating these factors, it will be possible to raise individuals who are more successful in science and who can integrate their engineering and mathematics knowledge into science subjects. 
The science curriculum should be put into practice by making a strong integration with STEM Education. At the same time, it is thought that the desired goals will be achieved through regulations such as arranging the content of the textbooks, increasing the course hours or allowing time for afterschool activities. Schools can be provided with the necessary equipment for experiments and activities, which can be conducted to achieve learning in students. It is thought that permanent learning can be realized by increasing the experiments and activities to be done together with the supply of the necessary tools and equipment to the schools. For the science course, laboratory classes related to the engineering field can be held. Many experiments can be carried out by having a small science laboratory in each school and providing basic materials.

\section{Lisans Bilgileri}

e-Kafkas Eğitim Araştırmaları Dergisi'nde yayınlanan eserler Creative Commons Atıf-Gayri Ticari 4.0 Uluslararası Lisansı ile lisanslanmıştır.

\section{Copyrights}

The works published in e-Kafkas Journal of Educational Research are licensed under a Creative Commons Attribution-NonCommercial 4.0 International License.

\section{Etik Beyannamesi}

$\mathrm{Bu}$ çalışmada "Yükseköğretim Kurumları Bilimsel Araştırma ve Yayın Etiği Yönergesi" kapsamında belirtilen kurallara uyulduğunu ve "Bilimsel Araştırma ve Yayın Etiğine Aykırı Eylemler" başlığ 1 altında belirtilen eylemlerden hiçbirini gerçekleştirmediğimizi beyan ederiz. Aynı zamanda yazarlar arasında çıkar çatışmasının olmadığını, tüm yazarların çalışmaya katkı sağladığını ve her türlü etik ihlalinde sorumluluğun makale yazarlarına ait olduğunu bildiririz.

\section{Etik Kurul İzin Bilgileri}

Etik kurul adı: Hatay Mustafa Kemal Üniversitesi

Etik kurul karar tarihi: 05.03.2020

Etik kurul belgesi sayı numaras1: :21817443-050.99 


\section{References}

Akgündüz, D. Aydeniz, M., Çakmakçı, G., Çavaş, B., Çorlu, M., Öner, T. \& Özdemir, S. (2015a). Turkey STEM education report: "Did requirements of today's fashions or do?". Istanbul Aydın University STEM center and education faculty.

Akgündüz, D., Ertepınar, H., Ger, M. A., Kaplan Say1, A. \& Türk, Z. (2015b). STEM education workshop report, a comprehensive assessment of Turkey on STEM education. Istanbul Aydın University STEM center and education faculty, 1-16.

Altun, Y. \& Yildırım, B. (2015). Investigating the effect of STEM education and engineering applications on science laboratory lectures. El-Cezerî Journal of Science and Engineering, 2(2), 28-40.

Aslan, F. \& Bektaş, O. (2019). Determination of pre-service science teachers' views regarding STEM applications. MM-International Journal of Educational Sciences, 3(2), 17-50.

Baran, E., Canbazoglu Bilici, S., Mesutoglu, C. \& Ocak, C. (2016). Moving STEM beyond schools: students' perceptions about an out of school STEM education program. International Journal of Education in Mathematics, Science and Technology, 4(1), 9-19.

Borg, W. R. \& Gall, M. D. (1989). Educational Research. An Introduction 5th. Edn. New York: Longman.

Büyüköztürk, Ş. (2016). Experimental patterns and data analysis book. Pegem Publication.

Bybee, R. W. (2010). What is STEM education? Science, 329, 996. DOİ: 10.1126/science.1194998.

Ceylan, S. (2014). A study for preparing an instructional design based on science, technology, engineering and mathematics (STEM) approach on the topic of acids and bases at secondary school science course. (Unpublished master's thesis). Akdeniz University, Insitute of Education Sciences, Antalya.

Creswell, J. W. (2019). A concise introduction to mixed methods research (Ed.: M. Sözbilir). Pegem Academi Publication

Çavaş, B., Bulut, Ç., Holbrook, J. \& Rannikmae, M. (2013). An engineering-oriented approach to science education: ENGINEER project and its applications. Journal of Science Education, l(1), 12-22.

Çorlu, M. A., Adıüzel, T., Ayar, M. C., Çorlu, M. S. \& Özel, S. (2012). Science, technology, engineering and mathematics (STEM) education: Interdisciplinary work and interactions. X. National Science and Mathematics Education Congress. Niğde.

Dass, P. M. (2015). Teaching STEM effectively with the learning cycle approach. K-12 STEM Education, 1(1), 5-12.

Doppelt, Y., Mehalik, M. M., Schunn, C. D., Silk, E. \& Krysinski, D. (2008). Engagement and achievements: A case study of design-based learning in a science context. Journal of Technology Education. 19(2), 22-39.

Erdoğan, N., Çorlu, M. S. \& Capraro, R. M. (2013). Defining innovation literacy: Do robotics programs help students develop innovation literacy skills? International Online Journal of Educational Sciences, 5(1), 1-9.

Ergün, A. \& Balçın M. D. (2019). The effects of problem-based STEM applications on academic success. The Journal of Limitless Education and Research, 4(1), 40-63. DOI: $10.29250 /$ sead.490923

Fidan, T. \& Öztürk, İ. (2015a). Perspectives and expectations of union member and non-union member teachers on teacher unions. Journal of Educational Sciences Research, 5(2), 191-220.

Fortus, D., Dershimer, R. C., Krajcik, J. S., Marx, R. W. \& Mamlok Naaman, R. (2004). Design-based science and student learning. Journal of Research in Science Teaching, 41(10), 1081-1110.

Fraenkel, J. R. Wallen, N. \& Hyun, H. H. (2012). How to design and evaluate research in education. 8th Edition, Newyork: McGraw-Hill International Edition.

Heppner, P. P. \& Petersen, C. H. (1982). The development and implications of a personal problem solving inventory. Journal of Counseling Psychology, 29, 66-75.

Harkema, J., Jadrich, J. \& Bruxvoort, C. (2009). Science and engineering: Two models of laboratory investigation. The Science Teacher, 76(9), 27-31.

Hovardaoğlu, S. (2000). Research techniques for behavioral sciences. Ve-Ga Publication. 
Irkıçatal, Z. (2016). STEM related after school program activities and associated outcomes on students' success and on their stem perception and interest. (Unpublished master's thesis). Uludağ University, Insitute of Education Sciences, Bursa.

Kerlinger, F. N. (1973). Foundations of Behavioral Research. 2nd ed. Holt, Rinehart and Winston.

Marulcu, İ. \& Hobek, K. M. (2014). Teaching Alternate Energy Sources to 8th Grades Students by Engineering Design Method. Middle Eastern and African Journal of Educational Research, 9, 41-58.

Miaoulis, I. (2009). Engineering the K-12 curriculum for technological innovation [White paper]. Retrieved from http://legacy.mos.org/nctl/docs/MOS_NCTL_White_Paper.pdf.

Miles, M, B. \& Huberman, A. M. (1994). Qualitative data analysis: An expanded Sourcebook. (2nd ed). Thousand Oaks, Sage.

Moore, T. J., Stohlmann, M.S., Wang, H. H., Tank, K. M. \& Roehrig, G. H. (2013). Implementation and integration of engineering in K-12 STEM education. College Engineering Education Research Magazine. Rotterdam, the Netherlands: Sense Publishers.

Morrison, J. (2006). Attributes of STEM education: The student, the school, the classroom [Monograph]. Baltimore, MD: Teaching Institute for Excellence in STEM. Retrieved from http://www.psea.org/uploadedFiles/TeachingandLearning/Career_and_Technical _Education/Attributes\%20of\%20STEM\%20Education\%20with\%20Cover\%202 \%20.pdf.

Özdemir, S. (2016). Insights for STEM education. Ankara.

Parno, Yuliati, L., Munfaridah, N., Ali, M., Rosyidah, F. U. N. \& Indrasari, N. (2020). The effect of project based learning-STEM on problem solving skills for students in the topic of electromagnetic induction. Journal of Physics: Conference Series. https://iopscience.iop.org/article/10.1088/1742-6596/1521/2/022025/pdf

Patton, M.Q. (2002). Qualitative research and evaluation methods (3rd Ed.). Sage Publications.

Roberts, A. (2012). A justification for STEM education. Technology and engineering teacher. Retrieved from http://www.iteaconnect.org/mbrsonly/Library/TTT/TTTe/04-12roberts.pdf.

Saçan, E. (2018). Stem-based curriculum proposal and effectiveness for science applications course. (Unpublished master's thesis). Hacettepe University, Insitute of Education Sciences, Ankara.

Satchwell, R. \& Loepp, F. (2002). Designing and implementing an integrated mathematics, science, and technology curriculum for the middle school. Journal of Industrial Teacher Education, 39(3), 41-66.

Strong, M. G. (2013). Developing elementary math and science process skills through engineering design instruction. Hofstra University.

Şahin, N., Şahin, N. H. \& Heppner, P. P. (1993). The psychometric properties of the problem solving inventory in a group of Turkish university students. Cognitive Therapy and Research, 17(4): 379-396.

Şahin, A. Ayar, M. C. \& Adigüzel, T. (2014). Out-of-school activities involving science, technology, engineering and mathematics and their effects on students. Kuram ve Uygulamada Eğitim Bilimleri. 14(1), 1-26.

Taşar, M. F. (2003). Teaching history and the nature of science in science teacher education programs. Pamukkale University Journal of Education, 1(13), 30-42.

Toma, R. B. \& Greca, I. M. (2018). The effect of integrative STEM instruction on elementary students' attitudes toward science. Eurasia Journal of Mathematics, Science and Technology Education, 14(4), 1383-1395.

TUSIAD. (2014). A research on demands and expectations for a workforce trained in STEM (Science, Technology, Engineering and Mathematics). TUSIAD.

Wendell, K. B. \& Lee, H. S. (2010). Elementary students' learning of materials science practices through instruction based on engineering design tasks. Journal of Science Education and Technology, 19(6), 580-601.

Yamak, H., Bulut, N. \& Dündar, S. (2014). The impact of STEM Activities on 5th grade students' scientific process skills and their attitudes towards science. GEFAD / GUJGEF 34(2), 249265.

Yildirım B. \& Selvi M. (2016). Examination of the effects of STEM education integrated as a part of science, technology, society and environment courses. International Human Science, 13(3), 112 . 
Zeynelgiller, O. (2006). The effect of the use of models in chemistry subject of science lesson in secondary schools on students' success. (Unpublished master's thesis). Celal Bayar University, Institute of Education Sciences, Manisa. 
e- Kafkas Eğitim Araştırmaları Dergisi (e-Kafkas Journal of Educational Research)

\section{Appendix}

\section{MADDELERIN ISI ILETKENLIĞINI SINIFLAYALIV}

ETKiNLiK -1 : Renkli bardaklar tasarliyoruz.

ETKiNLiĞiN AMACI: Maddelerin ısı iletkenliklerinin birbirinden farklı olduğunu tespit etmek.

ETKiLiĞiN VAPıLıșı: Farklı maddelerden yapılmış kulplu bardakların içerisine aynı miktarda sıcak su konulur ve en erken isınan bardak hangisi olduğu belirlenir.

GEREKLI MALZEMELER: Pet şişe, kutu kola, karton bardak, su, boya.

AŞAĞIDAKI SORULARI ETKINLIĞI YAPTIKTAN SONRA CEVAPLAYINIZ.

1.Etkinlikte ilk önce Isınan bardak hangisidir?

Kutu-Kolo

2. Maddelerin ısı iletkenliklerinin birbirinden farklı olduğunu açıklayınız

Metal daho çok isinir.

Diḡenter daha az isinir.

3.Etkinlikte yapmışolduğumuz bardakların iletkenliklerini azdan çoğa doğru sıralayınız

\section{Pet sișe, Karton bardak. Kutu bola}

4. Metal ve tahta kaşık suyun içerisinde eşit sürede bekletiliyor. Hangi kaşığın daha önce ısınnması beklenir? Nedenini açıklayınız.

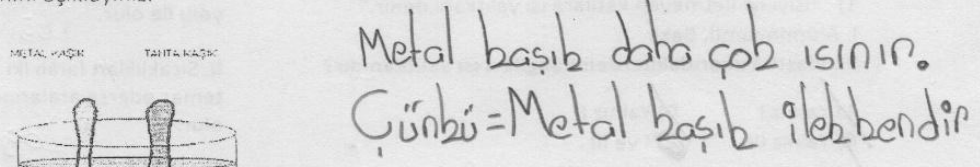


5.Madde Isı aldığında veya ısı verdiğinde maddelerin taneciklerinin hareketi ile ilgili olarak ne söylehebilir?

6.Maddenin üç hâlinin ısıyı iyi iletenden ısıyı iyi iletmeyene doğru sıralamasını yazınız.

Kat, Siv1, Goz

Aşağıda boș bırakılan yerleri uygun sözcüklerle doldurunuz.

- Maddelere ısı verildiğinde, taneciklerin hareketleri ....... öol. I.

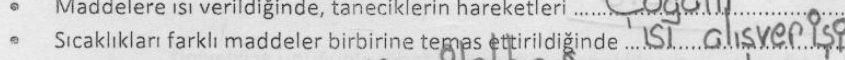

- Isıy iyi ileten maddelere .........LI........ E. D. E. D. denir.

- Isır iyi iletmeyen maddelere .IS.I........I. ban!..... denir

- Isiyi .......... Kat............... maddeler ..............

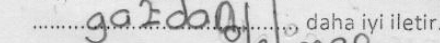

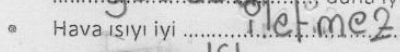

- $\quad \ldots . . . . . . . . . . . . . . . .5 \mid$.............. bir maddenin atom ya da moleküllerinin birbirlerine temas etmesiyle sıcak uçtan soğuk uca iletilmesidir.

Aşağıdaki cümlelerde doğru olanların başına " $D$ ", yanlış olanların başına " $\gamma$ " harfí yazınız.

1) () Gözenekli katılar ısıyı iyi iletir

2) (ID) Gazlar Isıyı iyi iletmez.

3) ( Isıyi ileten maddelere ısı yalıtkanı denir.

4) (1)isıyı ileten maddelere "Isı iletkeni" denir.

5) (i1) Sıcaklıkları farklı olan maddeler birbirine temas ettirilirse ısı alışverişi olur.

6) (D)sı, bir enerji türüdür

Așağıdaki soruları cevaplayınız.

1) "Isıyı iyi iletmeyen katılara ısı yalıtkanı denir."

I. Alüminyumil. Bakır

III. PlastikYukarıdakilerden hangileri ısı yalıtkanıdır?

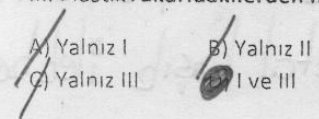

2)

I. Katı maddelerde ısı aktarımı konveksivon yolu ile olur.

II. Sıcaklıkları farklı iki madde birbirlerine temas ederse aralarında ısı alışverişi olur.

III. Sicak bir madde kendinden soğuk bir ortamda bulunduğunda çevresine is

yayar.

Vukarıdaki ifadelerinden hangileri doğrudur?

A) I ve II S) I,ve III

ive III D)।, II ve III 